\title{
JAPANESE YOUNG PEOPLE’ PERCEPTIONS OF RUSSIA
}

\author{
L.V. Zhilina \\ Dostoevsky Omsk State University, Omsk, Russian Federation
}

\begin{abstract}
This paper explores the dynamics of changing perceptions of Russia by Japanese young generation. The aim of the paper is to examine attitude toward Russia among young Japanese people, and to investigate factors that affect their "distant neighbor" perceptions and attitudes, and how it has changed within five years. As relations between Japan and Russia grow more complex, the need for more knowledge for mutual understanding is getting great.

It is based on a series of more detailed data analyses of the polls conducted at the Universities of Japan - as a part of research project "Student's Representations of neighboring countries at the beginning of $21^{\text {st }}$ century - Russia and Japan". In the research author turned to a student's audience, which is most perspective for acting with, on the way of creation of public opinion about foreign countries as well. Author address findings that obtained in 2007 and 2012 and use qualitative research methods, such as interviewing and discourse analysis. So, we provide an overview of findings from representative surveys and analyze findings from studies to draw conclusions about the drivers of changing public perceptions towards Russia.

Presented research is an illustrative explanation - stereotyped images are long-lasting and durable. They are difficult to change and can be passed on as heritage from the past.

Author concludes that although in general at the level of the University students' perceptions towards Russia have not been changed, but in details we can see some quantitative changes. The results indicated that some Japanese students held quite optimistic opinions toward Russia, but there was also evidence that public opinions toward Russia differed across the students and sometimes not in positive way.
\end{abstract}

Key words: perceptions of countries; Japan; national images; cross-cultural studies; young generation of Japan

\section{INTRODUCTION}

East Asian politicians have tended to see Russia as a "distant neighbor" with a distinct civilization - neither European nor Asian - and political and strategic interests at odds with their own ${ }^{1}$. It is obvious that an image of a nation comprises three layers: cognitive attributes (the perceived characteristics of the nation), affective attributes (the liking or disliking of the object), and action attributes (the responses to the object) [Scott 1966:100]. It indicates that the perceptions of one country that people of another country hold will influence the attitudes and policies of this country toward another country. This will in turn contribute to the multi-faceted dynamics of international relations. The responses of individual and collective actors in the world to an object

${ }^{1}$ Akaha, T. A Distant Neighbor: Russia's Search to Find Its Place in East Asia, Global Asia, June 20, 2012. URL: http://www.globalasia.org/Issue/ArticleDetail/206/a-distant-neighbor-russiassearch-to-find-its-place-in-east-asia.html (accessed: 04.11.2017). 
tend to be decided by its recognized image rather than the object itself ${ }^{2}$. Most decisions in international politics are based on misconceptions and distorted images for governmental leaders, decision-makers, and 'non-decision-makers' in the public are rarely aware that they are living in a world of images [Kunczik 1997; Whitehead 1987]. As a result, improper conclusions and assumptions, or international conflicts occur. The purpose of present paper is to explore public opinions on Russia among Japanese students, and try to investigate factors that affect their attitude.

\section{METHODOLOGY}

Following the tradition in image-related studies, the paper mostly relies on empirical research methods, such as interviewing and discourse analysis. So, we provide an overview of findings from representative surveys and polling data carried out in 2012 and 2007 and analyze findings from studies to draw conclusions about the drivers of changing public perceptions towards Russia.

There were some reasons why our questionnaire/opinion poll was conducted at the universities ${ }^{3}$. One of them is communication skills: "persons with more formal education are expected to have the higher reading and comprehension abilities necessary to acquire public affairs or science knowledge" [Tichenor et al. 1970]. A second - is amount of stored information, or existing knowledge resulting from prior exposure to the topic through mass media or from formal education itself: "persons who are already better informed are more likely to be aware of the topic when it appears in the mass media and are better prepared to understand it" [Zhilina 2009]. A third — is relevant social contact: "education generally indicates a broader sphere of everyday activity, a greater number of reference groups, and more interpersonal contacts, which increase the likelihood of discussing public affairs topics with others" [Katz 1961]. A fourth includes selective exposure, acceptance, and retention of information. As Sears and Freedman have pointed out, "voluntary exposure is often more closely related to education than to any other set of variables" [Sears, Freedman, 1967]. They contend that what appears to be selective exposure according to attitudes might often more appropriately be called 'de facto' selectivity resulting from educational differences. Selective acceptance and retention, however, might be a joint result of attitude and educational differences. Also, Joseph Klapper studied the categories of change that are affected by the media and explained the tendency of media to interpret and recall information in ways congruent with existing within an audience' beliefs and values [Klapper 1960]. The fifth and final reason is the nature of the mass media system that delivers information. Thus far, most science and public affairs news (with the possible recent exceptions of crisis events) is carried in print media that has traditionally been more heavily used by higher-status persons: "highly educated persons are more likely to have been

${ }^{2}$ Choi, J. (2006). Framing the national image of North Korea in the U.S. news media. URL: http://www.allacademic.com//meta/p_mla_apa_research_citation/0/9/2/4/7/pages92479/p92479-1.php) (accessed: 04.11.2017).

32007 - Japan Women's University (JWU, Tokyo, Japan) and 2012 - Aoyama Gakuin University (AGU, Tokyo, Japan). 
exposed to a heavily publicized topic in the past; they are already 'in motion' on this topic and are easier to move still farther than less educated persons" [Zhilina 2009: 194]. And university attendance has been shown to lower prejudice levels and increase global issue awareness. For these reasons, the opinions of university students must be an important consideration for the research.

\section{Sample Composition, Size Determination and the Questionnaire}

To represent the possibility that views and opinions may have been specific to certain groups the stratified random sample system was employed as the most logical choice for this study. Although the age variance range within the universities was relatively small in size, it was deemed important to attempt to chronicle how students' views and opinions evolved throughout the time spent at university. In other words, how education affected their views of the world, but more specifically their neighbors. Smaller samples are more economical for research purposes and can be better controlled to minimize errors. It is an established fact that a properly chosen sample can be perfectly representative of the whole population. The method of random stratification essentially allocates quotas to specific identifiable characteristic groups and is very convenient for small population sets. For research on large populations the sample size averages between 400-600 respondents. Further, having the enrolment list of the university, it was easiest for practical purposes to identify distinguishable stratification within the population and thereafter randomly select respondents within these strata to achieve the appropriate sample size for enquiry. Strata were defined along parameters of faculty and year of program.

The opinion survey on Russia was conducted at Japan Women's University (JWU) in June 2007. Following established methodological principles, the optimal sample size for research was determined to be 400 students. For this study, general population strata were defined along two criteria, age and faculty: age (18 - 19 years old, 19-20 years old, 20-21 years old, 21-22 years old). Essentially an equal number of students from each age group was randomly selected for participation from each faculty fulfilling quotas for representation of population variance in the sample. In the case of JWU sex could not be a determinant factor for fulfilling quotas as the general population of respondents were all female [Zhilina 2008]. The sample was produced from homogeneous sets as the number of "nits" in the general population was sufficient.

The same opinion survey on Russia (knowledge of Russia, Russian people, the national character of Russian people and their features, sources of information about Russia) was conducted in June 2012 in Aoyama Gakuin University (AGU). The optimal sample for the population size was determined to be 400 persons; the same as JWU. Sampling was conducted along similar principles that guided JWU research; stratified random stratification but in the case of AGU the sample also had to be stratified by sex (male or female), in addition to the other "standard" criteria - age (16 - 17 years old, 18 years old, 19 years old, 20-21 years old that generally corresponded to $1 \mathrm{st}, 2 \mathrm{nd}$, 3rd, and 4th year students), and lastly, faculty. The respondents to the questionnaire on Japan were also presented with 2 types of questions: "close-ended" (multiple choice answers) types and "open-ended" ("what do you think about...?"). 
As above mentioned, the study covers the period from 2007 to 2012 . The opinion polls were conducted two times with five years' interval with using a similar questionnaire. A focus of the surveys has been to measure public attitudes toward Russia; other questions have examined students' knowledge about Russian economy, Russian national character, and main sources of information about neighboring country. We wanted the Japanese students to challenge what they see and hear with solid arguments supported by evidence that they have evaluated and judged to be sound. This ability requires that they are willing to consider a broad range of perspectives and sources of knowledge. But present paper deals with perceptions of Russia by individuals, with shared meanings that are characteristic of groups in a society, which makes purposeful sampling particularly appropriate. As for the examination of perceived national images, interviews with groups (university students) are the best choice for this survey. The questions prepared for interviews provide participants more space and opportunity to offer private opinions on researched topics. Also, these studies can provide the most solid insight into the reasons behind changing Japanese public perceptions toward Russia. As previously noted, to understand the visions on Russia of the students we analyzed their answers. The analysis proposes to demonstrate that the differences of countries' perception involve the student's socioeconomic status and personal experiences.

\section{“A DISTANT NEIGHBOR”}

National images, as stereotypes, are not simply summaries of the information that one has about a state in the international system - they serve an informationreduction function and enrich our understanding of our bilateral relationships. They may simplify our views of the world, but they do so by adding interpretative elements that were not there in the first place [Castano et al. 2015: 2]. Any perceived images of foreign countries are not monolithic. They contain many components, such as an image of the authorities and the political leader, an economic image, an image of the country as an investment or tourist destination, etc. There can be a significant difference in perceptions of these elements: some of them can be viewed more negatively while others - more positively. Also, we should note that Russia's images differ substantially across countries as a result of various factors such as the history of their relations with Russia, the structure of economic relations, geographic proximity, etc. Moreover, there are also competing images within each individual country — in public opinion, in the mass media and etc. [Feklyunina 2009: 28]. Thus, while analyzing Russia's perceived images, we should take all these factors into consideration.

Images and perceptions of Japanese students' first impressions of Russia were gauged by asking them to name what they thought of when they heard the word "Russia". There were no blanks in responded questionnaires in 2007. In 2012, 3\% of respondents had not any associations with Russia - "No answer".

According to analysis of the questionnaire regarding representation of Russia, a trend was observed among a majority of Japanese students: they identified Russia with "cold climatic conditions", "image of cold country", where "it's always cold", "severe, terrible winter", "low temperature", "strong cold", "snow country", "image of cold country, where the people wear fur caps and many clothes" (2012 - 16.1\%, 2007 - 25.9\%). Here we could see that considering climate and nature of Russia, these attributes in- 
fluence the creation of country image, to a large extent depending on the background of the person in question. In 2007, there were also amusing statements such as: "They eat ice-cream to increase their body's temperature" [Zhilina 2008]. In 2012 there were some interesting connections in this group of associations: "cold - fur coat" and "cold - Eskimo (ice-cream)".

Table 1 demonstrates that in 2012 13.8\% (2007 - 9.7\%) of Japanese students associated Russia with geographical associations' key words. To be geographically informed, a person must keep in mind a lot of information about people, places, and environments, and must be able to organize the information in the appropriate spatial contexts ${ }^{4}$. Russia's image for Japanese youth is one of "the biggest countries in the world", "It occupies a huge territory", "Northern country", "Siberia" and "the country near Hokkaido Island". Students mentioned not only in terms of civilization but also politically and economically that Russia — "distant neighbor", "neither European nor Asian", "Geographically, Russia is a very big part of East Asia." So, we can assume that students develop and refine their mental maps ${ }^{5}$ both through personal experience and through learning from media and teachers. Then they continue adding information so that maps reflect a growing understanding of a changing world. That critical geographic observation is essential to this development and refinement process, because mental maps reflect students' skill in observing and thinking about the world in spatial terms ${ }^{6}$.

Table 1

Words associated with "Russia" (in 2012 and 2007)

\begin{tabular}{|l|c|c|c|}
\hline \multicolumn{1}{|c|}{ Associations with Russia } & Survey 2007 (\%) & Survey 2012 (\%) & Changes \\
\hline Cold climatic conditions & 25.90 & 16.10 & -9.80 \\
\hline Geographical associations & 9.70 & 13.80 & +4.10 \\
\hline Historical and political figures & 8.90 & 7.20 & -1.70 \\
\hline $\begin{array}{l}\text { USSR, socialism, Communism, Communist } \\
\text { Party of the Soviet Union (CPSU) }\end{array}$ & 8.30 & 7.90 & -0.40 \\
\hline Negative incidents and facts & & & -1.40 \\
\hline Sport and sportsmen & 7.50 & 6.10 & -2.90 \\
\hline National cuisine & 6.60 & 3.70 & +0.80 \\
\hline National symbols & 6.30 & 7.10 & -1.30 \\
\hline National dances, ballet, shows & 5.70 & 4.40 & -2.90 \\
\hline Beautiful people (women) with white skin & 4.60 & 1.70 & +1.50 \\
\hline Northern territories & 4.60 & 6.10 & +2.4 \\
\hline Particular color & 2.80 & 5.20 & -0.10 \\
\hline Others & 2.70 & 2.60 & +8.70 \\
\hline No answer & 6.40 & 15.10 & +3.00 \\
\hline
\end{tabular}

Created by the author on the base of polls conducted at the Universities of Japan in 2007/2012.

4 The power of place Geography for the $21^{\text {st }}$ century: The Geography Education Standards Project. URL: http://www.learner.org/series/powerofplace/standards.html (accessed: 01.11.2017).

5 In modern studies term "a mental map" means an image of space (in person's mind) which is formed under the influence of important social, cultural and historical peculiarities of space, and due to the personality traits of the person and his attitudes towards the environment. Mental map is a mixture of both objective knowledge and subjective perceptions of the person. It helps person to form and develop natural image of the world.

${ }^{6}$ The power of place Geography for the $21^{\text {st }}$ century: The Geography Education Standards Project. URL: http://www.learner.org/series/powerofplace/standards.html (accessed: 01.11.2017). 
As we could see geopolitical imaginations were the prevalent images for Japanese respondents. Such geopolitical orientations represent a relatively volatile element of political culture and identity that can be changed under the influence of media and other factors of conjuncture and "with the development of mass culture, communications and social mobility, the importance of political orientations is growing, worked out through the process of socialization" [Kholodkovsky 1979].

Japanese students' perception of places and regions is not uniform. Rather, their view of a place or a region is their interpretation of its location, extent, characteristics, and significance as influenced by their own culture and experience ${ }^{7}$. Much more consistently, results of this research show that Russia-related attitudes are mostly driven by symbolic concerns about the nation as a whole.

\section{HISTORICAL IMAGES AND POLITICAL LEADERS}

Images of other nations are affected by history as well. An individual's image of an object at the present is correlated to people' views of its past and future. For instance, Michael Kunczik comments that "many prejudices about nations are carried forward through generations, so that historical events of long ago remain decisive in a nation's image" [Kunczik 1997: 3] and the international relations (e.g. wars, hostilities, friendliness, and alliances, military, economic and political compatibility) of countries, either in the past or present, play a role in national image perceptions. Owing to the dynamic and constantly changing nature of images, image study should be placed in a historical context.

As for Japanese students, they linked their representations about Russia with "USSR, socialism, Communism and Communist Party of the Soviet Union (CPSU)" (2012 $7.9 \%, 2007-8.3 \%$ ) — "The strong image of socialism and the collapse of the Soviet Union", "The image of the country where the background of the socialism remains", "The Former Soviet Union". Image of communist Russia and later of the Soviet Union was a strong association with Russia as well. Following the collapse of the Soviet Union, Russian images in Japan underwent transformation - relatively positive in the early stage, they became more negative towards the end of 2000's and reached the negative peak [Zhilina 2015: 14]. These associative definitions indicate a strong association between Russia and the USSR - young people sensed Russia's complicated political position, a paying more attention to Russia's domestic and international position. In some ways the most famous, certainly the most iconic of all Soviet institutions, the KGB was also, and still remains as strong association with Russia for Japanese students: "The USSR and KGB"; "KGB, the police, CPSU". We can suggest that one of the reasons is the Cold War years when Russia was a land that was off limits for most foreigners. Some of Japanese students associated Russia with "former Soviet republics", especially "Ukraine, Belarus, and Kazakhstan". The share of respondents who expressed their concern about Russia's behavior towards its neighbors was considerably larger in the public opinion of Japanese students in 2007 than in 2012.

7 The power of place Geography for the 21st century: The Geography Education Standards Project. URL: http://www.learner.org/series/powerofplace/standards.html (accessed: 21.10.2017). 
The results of the surveys produce interesting factual material for the description and analysis of the image of political figures - some of Japanese students associated Russia with historical and political figures of Russia (2012 - 7.2\%, 2007 - 8.9\%). In this context, respondents recalled the names of President Putin, Gorbachev, Lenin, Stalin, Catherine II, and Tsar Romanov. Some of the Japanese respondents had knowledge of the history of Russia at an average level, while some of them had poor knowledge of the history (knowledge only some of important names). Gender differences in the two groups of respondents were not found. A large majority of students surveyed associated Russia with "Putin" — 70.7\% of respondents, mentioning political figures in association with Russia. Here we can see the dominant image of Russian President this personification is official emblem of the nation, and it's widely recognized. As we could see: special part in the overall image of the country and the nation declared by the young Japanese people played political and historical personages. In fact, the majority of Japanese students paid bigger attention to Russia's historical and political figures position associating them with Russia. Students frequently identified Russia with: "Putin, KGB"; "Putin and Troika"; "Putin and Northern Territories"; "Putin, KGB, Army" or "I know only Putin, that's why it's strong association". A Russian leader is always a subject of international importance and V. Putin is that person for Japanese students. It means that his figure is an object of interest on the part of the world community. Students frequently mentioned the name of Vladimir Putin in different situational contexts of association with Russia and the Russians' national character. As we can see, political leaders are increasingly assonated with their country esteem abroad.

\section{NEGATIVE EMOTIONS: FROM PAST TO PRESENT}

International Image Theory posits that three dimensions of bilateral state-to-state relations ${ }^{8}$ determine which national image will be activated [Castano et al. 2015: 3]. The negative images of Russia were viewed by Japanese students as a serious threat of Russian security. According to the findings, it can be stated that Russia has been found to bear mixed image ${ }^{9}$. Some negative Japanese images of Russia were replaced by new positive images and vice versa, while some negative stereotypes remained unchanged. But the number of Japanese students who associate Russia with "Negative incidents and facts" has decreased from 7.5\% (2007) to 6.1\% (2012). Despite the fact that Russia is renowned for its tourism attractions however such aspect as crime is argued to damage the image of Russia. With the alarming increase of terrorism activities in most parts of the world, the issue of safety is ranked as high important when possibility of tourism to one or another country is discussed.

${ }^{8}$ First, goal compatibility: whether the other state is threatening, can be exploited, or represents an opportunity for mutual gain. Second, is the other state weaker, comparable in capability, or stronger? Third, national images include a cultural judgment: how sophisticated is the other nation, and what norms is it likely to respect?

${ }^{9}$ Mixed image implies a country being perceived with positive and negative image which might derive through two or more contradicting factors, mainly positive and negative. 
An illustrative example of these views is that Russia's image for the Japanese students is very mixed but we could separate them into groups based on data of 2007 and 2012 surveys:

- Negative incidents: the war in Chechnya is a component of negative image.

- Hard social conditions: "Society gap is big", "People are poor", "Life is hard".

— Low level of safety in society: "Danger", "Russian Mafia", "Killing", "There are many crimes", "Now, public safety is bad", "Terrorism", etc.

- Cold War: "The image of the Cold War in the Soviet period", "Cold War with post-war America".

— Instability: "Country where economy is not stable", "The society is still unstable".

- Bad relations with other countries: "There is image of the country which isn't on good terms with Japan", "The image of the country which is on bad terms with Japan", "It is not on good terms with Europe".

— Political, financial problems: "There are many problems in the politics", "There is no transparency in political situation", "Image of the country with financial difficulties (problems)", "Though it is a republic, its politics is monopolistic".

— Some historical facts: "Military State", "It fought against Japan many years ago", "The Russo-Japanese War".

R.K. Herrmann and M.P. Fischerkeller [Herrmann, Fischerkeller 1995: 426] argued that "the enemy image involves a foreign country that is seen as threatening and comparable to one's own country in power capability and cultural sophistication, while the degenerate image refers to a foreign country that can be exploited and is similar in capability but suffering from cultural decay". Obviously that Russia's negative images for young Japanese people were viewed as a serious threat for Russian security, particularly in terms of Russia's economic development. And in 2012 Japanese students also associated Russia with "Chernobyl". It was quite predictable to see such answers in process of that poll. One year before that survey (2011) it was the first range news in all TV-channels and media of the world - earthquake and tsunami off the north coast of Japan. Conversely, there was a comparison with Chernobyl disaster happened in 1986, when one of four nuclear reactors at the Chernobyl power station exploded.

Also, we should emphasize that number of Japanese students who linked their Russia's associations with the territorial disputes regarding the "Northern territories" has exponentially increased from $2.8 \%$ (2007) to 5.2\% (2012) — almost doubled. Moreover, in this connection (for illustration) we can mention the results of more recent opinion polls in 2014 "Japanese Value Orientations" Survey on Diplomacy ${ }^{11}$ : 2013 - 2015 (the events in Crimea and Ukraine) the share of Japanese people who held a favorable opinion of Russia dropped from 22.5 to $17.4 \%$,

10 Takahashi Koichi, Aramaki Hiroshi. Ji keiretsu chosa "nihon-no ishiki” hensen ("Japanese Value Orientations" as Reflected in the Changes of Survey Results over 40 years). Tokyo: NHK hoso kenkyūjo, 2014. July. P. 225-226.

${ }^{11}$ Naikakufu daijin kambo seifu kohoshitsu. Gaikō-ni kan-suru yoron chosa (Japanese Cabinet Information Research Office. Public Opinion Survey on Diplomacy 2016). URL: http://www.survey.gov-online.go.jp/h28/h28-gaiko/2-1.html (accessed: 07.01.2018). 
while the share of ill-wishers and the indifferent grew from 74.7 to $79.3 \%$. A survey conducted in Japan in 2014 showed some shocking results: Russia became the country that Japanese people "disliked the most". Fortunately, in 2016, the trend made a symbolic turn: the former grew a bit from 17.4 to $19.3 \%$ and the latter dropped from $79.3 \%$ to 76.9\% [Chugrov 2017: 23]. The Japanese people felt the events in Crimea particularly painfully, as they saw similarities with the Kuril Islands situation. What is more, antiRussian sentiments were artificially whipped up by the media.

\section{POSITIVE EMOTIONS: \\ FROM "PIES" TO "DOSTOEVSKY" AND "SPORTSMEN"}

As soon as Russia was opened by the Japanese students, they experienced influences of Russia across every aspect of life, including the culinary. The Russian culinary time-to-time is also the subject which Japanese media attention paid to. Other frequently identified aspect was national cuisine $(2012$ - 7.1\%, 2007 - 6.3\%). In general, many words used by the students are related to national cuisine. In the form of a traditional kind of dish: a dish now internationally known as "pies" and "borsch", "alcohol", "caviar". In $201247.5 \%$ of students who connected Russia with national cuisine, mentioned "vodka". It naturally leads to the conclusion that for students, image of Russia and the Russians closely linked with vodka. There were some interesting connections in this group of associations: "KGB — vodka — borsch"; "borsch — vodka Plyushchenko".

Public perceptions of foreign states are known to differ between nations - different cultures may have different perceptions and definitions of beauty and the media has influence on society's perception of beauty through magazines, tabloid newspapers and television. For instance, some of Japanese respondents $(2012-6.1 \%, 2007-4.6 \%)$ noted positive emotions in connection with "Russian people" in association with Russia and pointed them as "the beautiful people with white skin". Indeed, Russia is not just a geographical space for Japanese students. Russia is its "beautiful people", "beautiful girls with white skin". Basically, it means that visual beauty ideals about beautiful and look well-groomed Russian women in Japanese media are working. Therefore, it is necessary to take into account that Japanese society visual nature takes an important place in Japanese education system. Some students emphasized that "the color of the skin is white" and "skin is white and beautiful". Some students associate Russia with "pretty girls" and noted that "the Russians are tall", "Russian women are beautiful" and "there are many beautiful people like a doll in Russia". But there was a very telling response as it relates to how information received, ideas and stereotypes formed: "They say, that Russian women are very beautiful".

In 2012, almost $4.4 \%$ of respondents (2007 - 5.7\%) mentioned "national symbols" associative with "Russia". Every nation has a number of symbols or emblematic elements associated with it that are intrinsic to its identity and heritage. Japanese students associated the country with "Matryoshka"12, "Hats" and "Caps made from fur". Insufficient

12 A Russian doll is a hollow wooden doll that is made in two halves. Inside it are a series of similar wooden dolls, each smaller than the last, placed one inside the other. 
knowledge of traditions was revealed in the group of Japanese students. In some cases, they tried to interpret some native Russian traditions and rituals in different ways ${ }^{13}$. As merits are named: the deep Russian culture is not forgotten too - it is associated with the Bolshoi Theatre, Dostoevsky, and Leo Tolstoy. The symbols of Russia were declared to be a balalaika, the Kremlin and the Red Square as associative words with Russia. Russian literature representatives - Chekhov and Gorky were mentioned by some of the students in connection with image of Russia. Images of "poet Alexander Pushkin", "Saint Petersburg", and "Christian Cathedrals" were also pointed out.

Japanese youth associations with Russia — "Sports and sportsmen" (2012 - 3.7\%, 2007 - 6.6\%). In 2007 students mentioned frequently names of figure skater E. Plushchenko and tennis player M. Sharapova. Also, they noted: "Volleyball is strong. Synchronic swimming is terrific. Rhythmic sportive gymnastics is strong". But in 2012 we should stress that respondents have associations with Russia through the image of CSKA (Russian football club), the Japanese football player Honda Kesuke and Russian soccer player Arshavin ${ }^{14}$. There were some answers like this: "sambo wrestling — Putin". It is easy to see why these names were mentioned by Japanese respondents - EURO-2012 was taking place that time. These images of Russia operate in combination with individual preferences of students: football; volleyball is strong; figure skating; judo.

It is interesting to note that Japanese youth associated Russia with a particular "white — blue — red" color $(2012$ - 2.6\%, 2007 - 2.7\%). Most countries have national colors that are used to represent the country outside of standard icons like the flag. Sometimes national colors are frequently part of a countries' set of national symbols. But in 2007 some students also associated Russia with color: grey, grayish, dark, white. Only Japanese students have such original visual perceptions of Russia. In an era, which is increasingly dominated by the flow of images, contemporary Japan has a high profile, producing manga, anime, video games, etc. Manga, unlike comics in the West, is read by a larger segment of the population in Japan, regardless of age. Starting off as something akin to comic books, they have now taken on various forms such as animated series (anime) to graphic novels. This 'visual culture' is formed by numerous relationships between Japanese people and various images. Here it is important to emphasize Japan's unique cultural identity. Also, some students associated Russia with "show — performances" — national dances, ballet $(2012-1.7 \%, 2007-4.6 \%)$. But in 2007 respondents named Russian girls' pop-group TATU, as association with Russia (that year it was TATU-boom in Japan).

It was a big surprise for us: Japanese students listed "Laika", "Kudryavka" "Cheburashka" is another Russian invention immensely popular in Japan, perhaps even more so than in Russia itself, a cute little animal and the main protagonist in children's literature and the animation series of the same name, was also accepted as image of Russia.

13 Students tried to draw shaggy hats, sometimes looked like Cossack's hats.

${ }^{14}$ Survey 2012 was carried out in June.

15 Кудрявка (In Russ.) - chosen as the occupant of the Soviet spacecraft Sputnik-2 dog. It was launched into outer space on November $3^{\text {rd }} 1957$. 


\section{DISCUSSION: COUNTRY OF THE CONTRASTS}

National images, in fact, are one part of a state's soft power and play important role in international relations. Russia's image abroad is very mixed - sometimes with the negative traits dominating. Qualitative approaches in this research have provided the potential for considerable added value over quantitative surveys, providing far greater depth of explanation of students' attitude toward Russia, including the complexity of their cognitive and emotional engagement with topic involved. Looking at Japanese students' image of Russia more in detail, we can conclude that Russia is a very wellknown country in Japan - the neighbor in Asia-Pacific region. There are some strong positive elements in Russia's image as perceived by Japanese students. As we could see, although some negative elements constituted the core of the country's image of Russia, there were also some positive developments in Japanese students' perceptions of Russia and Russian culture - the most positive component of the nation's brand for Japanese students who linked their representation of Russia with names of Russian writers and Russian performing arts (as classical as modern). At the beginning of the $21^{\text {th }}$ century it was the boom of Russian literature in Japan — "The Brothers Karamazov" of F. Dostoevsky was translated into Japanese by Ikuo Kameyama ${ }^{16}$ and it was the eighth translation of Dostoevsky's masterpiece in Japan. The first one came out in 1920, the last — in the 1970's, but all of them were very difficult to read because of differences of language, and psychological points. Thanks to Prof. Kameyama who had developed several strategic points this book became the bestseller in Japan - especially it was most popular with young generation of the Japanese ${ }^{17}$. It is no doubt that culture exerts positive influence on nation's image and it plays an important role in the construction of national image. Its effect on Russia's overall image is, however, fairly limited as it was primarily the culture of pre-Soviet Russia that was widely known in Japan whereas Russian contemporary culture is considerably less visible.

Another positive perception of Russia in Japan is the interest in Russia's progress in sports, e.g. in tennis, figure skating, etc. These sportsmen created many fans among young generation in Japan. Friendly images of Russia for Japanese students may result from the performance of Russian achievements in sport; the Russian sportsmen are more popular in Japan than in any other country. At the same time, Russia is still seen by many young Japanese people 'as a stranger', i.e. as a country difficult to understand.

It is therefore possible to conclude that the images of Russia — "the cold country", "snowing country" with "huge territory" and "people in fur caps" invariably remain

${ }^{16}$ Japanese scientist and literary critic, Professor, Rector of the Tokyo Institute of Foreign Languages I. Kameyama "has added" "The Brothers Karamazov" by Dostoevsky. First, he had simplified and slightly reduced the names of the actors, as they (and especially - middle name) were very difficult to remember for the Japanese. Another key moment was the creation of an adequate translation of the Japanese rhythm. In the novel there are a lot of dialogue which are too hard for reading and listening. A lot of Japanese readers were just amazed by Prof. Kameyama's translation, they could not expect that Dostoevsky's text was so rhythmic.

${ }_{17}$ According to statistics from the Japanese public opinion polls revealed that about $50 \%$ of readers of the book are young, intelligent, working women aged a little over thirty. 
fixes in minds and beliefs. Differently, the space becomes not a neutral category for the students, and national stereotypes undoubtedly include images of space. They become national symbols (for instance: "the Kremlin", "the Red Square”, and so on) [Zhilina 2009]. It is possible to state that all the Russia' perceptions of Japanese respondents often colored by their memory of these places they have received through mediated visual information and images. We found out that Russia was defined by visual orientations of students. The young Japanese people characteristically associate Russia through visual narration. In these sequences, as well as others, the students' emotional reactions to events are typically captured in the visual presentation of Russia - country with "beautiful people". Visualization is the ability to mentally represent and manipulate information and images. When Japanese students visualize, they use images, symbols (e.g., pictures and colors), and other forms of mental coding to represent experiences and information. As mentioned above the degree of sympathy for the Japanese attitude toward Russia unfortunately it still remains low, but we could see some positive changes. The level of Japanese students' knowledge of Russia has been increasing. But there were remains of the atmosphere of the Cold War in the Japanese students' responses. Events and problems in Russia were described in political terms and moved as the consequence of the communist system. Students see the Russian Federation as the imperial successor of the Soviet Union. The war in Chechnya is a very important component of Russia's negative image. Another negative perception of Russia connected with Russia's sometimes difficult relations with the other former Soviet republics. Japanese students also cited strengthened state and political control over central TV-news channels ("speech control") as domestic developments that negatively impact their perceptions of Russia. The high crime rate in Russian society also tends to contribute to the negative the Japanese have of Russia. Also, we should add such Japanese students' negative representation of Russian society as the high crime rate; a difficult social situation; social injustices; corruption. It's difficult to ignore the fact that the percentage of respondents associated Russia with "territorial dispute" has increased since 2007. It is notable that the territorial issue dominates media coverage of Japanese-Russian relations. Obtained results indicated that Japanese students acquire knowledge about the characteristics of Russia from hot news in international print media and from attention to often negative news from TV, but the number of respondents mentioned "negative incidents and facts" has decreased by 2012. At the same time a global media culture provides new sources of information, sources for cross-cultural contact, and new cultural experiences for Japanese students. Although made analyses to date point to a role for some political and economic factors in particular as influences on students' perceptions toward their counterpart, other factors may also have affected the identified new trends. There are several other plausible influences on changing public perceptions, particularly in the context of growing skepticism towards Russia in some parts of the world. However, there has been little or no formal analysis of how these may have affected public opinion. In other words, at the group level longitudinal surveys reveal that mean Japanese young people feelings toward Russia remain remarkably consistent across time, with warmth toward Russian culture and sport, and coolness towards image of communist Russia with low level of safety in society where a lot of financial problems. 
Although in general at the level of the university students' perceptions toward Russia have not been changed, but in details we can see some quantitative changes. In Japan, public perceptions regarding their close neighbor - Russia have vacillated over the past decade. The results indicated that some Japanese students held quite optimistic opinions toward Russia, but there was also evidence that public opinions toward Russia differed across the students and sometimes not in positive way. However, the existence of the negative attitude did constitute a formidable challenge for RussianJapanese bilateral relations. In addition to that, some negative elements in Russia's images in Japan were reinforced by the inevitable emphasis on sensations in the Japanese mass media [Zhilina 2008].

In presented paper the primary focus was on attitudinal trends of changing attitudes and perceptions of Russia by Japanese young people. Data sources we have used here were primarily previous surveys. We have made an attempt to understand Japanese students' perceptions' (toward the neighboring country - Russia) transformations by using of 2007 and 2012 surveys' data and its analysis. Although five years have passed between the surveys we have made the more detailed analyses of presented here survey data, so our studies have been focused on some of the deeper sides of Japanese youth' attitudes toward Russia that may be slower to change. If there are no extraordinary changes or specific events in particular country or in bilateral relations, many underlying images and beliefs that each nation holds toward the other are likely to persist in at least the short to medium term. Presented research is an illustrative explanation - stereotyped images are long-lasting and durable. They are difficult to change and can be passed on as heritage from the past. It is fair to suppose that Japanese students attitude toward the Russians and Russia can be easily marked by the changing nature of the popular stereotype associated with the Russians from Soviet epoch. The historical legacy is still strong and little has been done or reported on in the media to change these stereotypes. As we have seen, the representations and attitude toward Russia are different in some ways. Indeed, cultural, religious and traditional beliefs which differ so significantly from one country to another create serious barriers to a smooth flow of news and information. Language, translation difficulties and ethnic biases are perhaps the most common sources of such problems. Any images tend to resist any changes, and as a consequence, any information that contradicts the existing image will be ignored. Therefore, only by being repeated many times this particular information can lead to changes in the image. But in spite of everything the image of Russia in Japan gradually improves.

The findings and analyses contained in the resulting reports of our project had established a minimum set of country-image-related views that can provide a standard for measuring changes in public opinion in our both countries over time. In fact, we hope to build upon this initial set of data and analyses to develop our project and carry out further surveys (one poll - in every five years), to chart changes in attitude as well as 'rapid reaction' polls designed to measure the impact of specific events or incidents on public views in our both countries over time. Moreover 2018 is declared the crosscultural year - Year of Russia in Japan and the Year of Japan in Russia - year 
of Russian-Japanese cultural exchange between the two nations. Within the framework of the Year of Russia in Japan a series of cultural and academic events based primarily in Tokyo but also featuring events at venues throughout Japan will be held with the aim of introducing the many facets of Russia to the Japanese people. The program of activities will particularly target the younger generations whose actions will determine future of the two countries. It will introduce both traditional and modern Russian culture and many other aspects of Russia. The ultimate goal of this cross-cultural year is to further strengthen the friendly relations that exist between the two nations by deepening mutual understanding which will serve as the way of country image improving and the foundation for a new partnership. In this connection author would like to propose carrying out further survey in 2019.

More in-depth analysis of proposed data would give an opportunity to examine the historical component in national images - particularly the impact of divergent views on Russia, including its role in the world perspective, on the dominant images in the two countries. Finally, future research should address the problem of wider issues related to projected national images. One can hope that the findings of this research will contribute to the conceptualization of the role of national images in international relations, and that the issues it has addressed will be developed further in future studies.

With the coming of globalized communication, there has been a surge in national image construction. It can not only create domestic political support but also enlarge a country's international influence. The latter function is deemed to be more crucial today since nations desire to integrate with global markets, to participate in global affairs, and to enhance their status on the world stage. The way how a country is perceived and projected by other countries can result in changes in their mutual relationships and to their strategic responses [Li, Chitty 2009: 1]. In presented study, a student population was examined because students have the greatest potential to influence public opinion and finally to participate in international policy decision-making and public affairs of a country. Clearly, some propositions that we have offered are not entirely unique, but it is not possible to extrapolate conclusions of the general population from the examination of Japanese university students, however, this study also serves as a window to an understanding of the process of forming of public opinion about neighboring countries and has highlighted some areas of opportunity where foreign policy may be directed to best cultivate positive attitudes and views that would rebound to closer economic and political ties.

\section{REFERENCES}

Castano, E., Bonacossa, A. \& Gries, P. (2015). National Images as Integrated Schemas: Subliminal Primes of Image Attributes Shape Foreign Policy Preferences. Political Psychology, 37(3), 351-366. DOI: 10.1111/pops.12259.

Chugrov, S.V. (2017). The Image of Russia in Japan and the Image of Japan in Russia: Working Paper 33/2017. Russian International Affairs Council (RIAC). Moscow: NPMP RIAC.

Feklyunina, V. (2009). National Images in International Relations: Putin's Russia and the West. Thesis PhD in Politics. University of Glasgow. 
Herrmann, R.K. \& Fischerkeller, M.P. (1995). Beyond the Enemy Image and Spiral Model: CognitiveStrategic Research after the Cold War. International Organization, 49 (3), 415-450.

Klapper, J.T. (1960). The Effects of Mass Communication. NY: Free Press.

Katz, E. (1961). The Social Itinerary of Technical Change: Two Studies on the Diffusion of Innovation. Human Organization, 20(2), 70-82.

Kholodkovsky, K.G. (1979). Some questions of the development of political mass consciousness. World Economy and International Relations, 6, 126-131. (In Russ.).

Kunczik, M. (1997). Images of Nations and International Public Relations. Mahweh, N.J.: Lawrence Erlbaum.

Li, X. \& Chitty, N. (2009). Reframing national image: A methodological framework. Conflict \& communication online, $8(2), 1-11$.

Scott, W.A. (1966). Psychological and social correlates of international images. In: International Behavior. Ed. by H.C. Kelman. NY: Holt, Rinehart and Winston, p. 70-103.

Sears, D.O. \& Freedman, J. (1967). Selective Exposure to Information: A Critical Review. Public Opinion Quarterly, 31, 194-214.

Tichenor, P.J., Donohue, G.A. \& Olien, C.N. (1970). Mass media flow and differential growth in knowledge. Public Opinion Quarterly, 34 (2), 159-170.

Whitehead, S. (1987). Arab Portrayals in U.S. and British News Magazines: A Comparative Analysis. Paper presented at the Annual Meeting of the Association for Education in Journalism and Mass Communication.

Yehuda, A. (1976). The role of intergroup contact in change of prejudice and ethic relations. In: Towards the elimination of racism. Ed. by Katz P.A. NY: Pergamon, p. 245-308.

Youichi, I. (1991). Socio-cultural backgrounds of Japanese interpersonal communication style. Civilisations, 39, 101-128.

Zhilina, L.V. (2008). Representations of neighboring countries at the beginning of $21^{\text {st }}$ century Russia and Japan in students' imaginations. Omsk: Omskblankizdat.

Zhilina, L.V. (2009). The forming of Japanese public opinion about Russia and the Russians at the beginning of the $21^{\text {st }}$ century. Herald of Omsk University, 3, 193-199. (In Russ.).

Zhilina, L. (2015). Public attitude and mutual perceptions: Japan and Russia. CEU Political Science Journal, 10 (1-2), 1-30. (In Russ.).

Acknowledgments: The author gratefully acknowledges The Japan Foundation for awarded Research Grants in 2007 and 2012; Prof. Yoshie Kira (Japanese Women University, Tokyo, Japan) and Prof. Podalko Petr E. (Aoyama Gakuin University, Tokyo, Japan) for conducting the surveys in 2007 and 2012 and students of these Universities for taking part in these surveys in Japan. Many thanks as well to Reiko Oomura (Instructor of Inter-Cultural Institute, Tokyo, Japan) for helping to interpret surveys data and Raisa Zhilina for helping to systematize the surveys data on which the analyses here are based; Eugeny Kruchina (secretary of Russia-Japan Society) and Bessem Elizabeth Manga (Counsellor Embassy of Cameroon in Paris) for their first-rate assistance in editing of this article.

Received: 17.11.2017

For citations: Zhilina, L.V. (2018). Japanese young people' perceptions of Russia. Vestnik RUDN. International Relations, 18 (1), 49-65. DOI: 10.22363/2313-0660-2018-18-1-49-65.

About the author: Zhilina Larisa Vladimirovna - PhD in History, Associate Professor of the Dostoevsky Omsk State University (e-mail: larissa-zhilina@yandex.ru). 


\title{
ВОСПРИЯТИЕ РОССИИ МОЛОДЫМ ПОКОЛЕНИЕМ ЯПОНИИ
}

\author{
Л.В. Жилина \\ Омский государственный университет им. Ф.М. Достоевского, \\ Омск, Российская Федерация
}

В работе исследуется динамика изменения восприятия России молодым поколением Японии. Цель статьи - рассмотреть, какие представления и стереотипы сложились у японской молодежи в отношении России, проанализировать факторы, влияющие на восприятие молодыми японцами «дальнего соседа», и то, как эти представления изменились за пять лет. По мере усложнения отношений между Японией и Россией возрастает потребность в получении большего объема знаний для выстраивания взаимопонимания.

Для более детального анализа в статье были использованы данные опросов, проведенных в университетах Японии в рамках исследовательского проекта «Представления студентов о странахсоседях в начале XXI века - Россия и Япония». Как представляется, студенческая аудитория наиболее перспективная для работы в плане формирования общественного мнения о зарубежных странах. Мы обращаемся к результатам, полученным в 2007 и 2012 гг., и используем эмпирические методы исследования, такие как опрос и анализ дискурса. Таким образом, мы предоставляем обзор результатов репрезентативных опросов и анализируем результаты исследований для того, чтобы сделать выводы о движущих факторах изменения общественного восприятия России молодыми японцами.

Представленное исследование является иллюстративным объяснением того, что стереотипы долговечны - их довольно трудно изменить — и они могут передаваться из поколения в поколение.

По результатам исследования автор пришел к следующему выводу: хотя в целом уровень восприятия России в студенческой среде не изменился, но, тем не менее, мы смогли увидеть некоторые количественные изменения. Результаты опросов показали, что определенная часть японских студентов придерживается довольно оптимистичного мнения о России. Однако были и свидетельства того, что по некоторым вопросам мнения японских студентов изменились, при этом иногда не в лучшую сторону.

Ключевые слова: восприятие стран; Япония; национальные имиджи; межкультурные исследования; молодое поколение Японии

Благодарности: Автор благодарит Японский Фонд за присужденные гранты на научные исследования в 2007 и 2012 гг;; профессора Кира Ёсиэ (Japanese Women University, Токио, Япония) и профессора П.Э. Подалко (Аоуаma Gakuin University, Токио, Япония) за участие в проведении опросов в 2007 и 2012 гг,, а также студентов этих университетов. Отдельное спасибо Рэйко Оомура (преподавателю Института Международной Культуры, Токио, Япония) за помощь в интерпретации данных исследования и Раисе Жилиной за помощь в систематизации информации, на которой основано исследование; ответственного секретаря Общества Россия-Япония Е.Н. Кручина и советника посольства Камеруна в Париже Бессем Элизабет Манга за их высококвалифицированную помощь в подготовке этой статьи.

\section{БИБЛИОГРАФИЧЕСКИЙ СПИСОК}

Жилина Л.В. Формирование общественного мнения о России и русских в Японии в начале XXI в. // Вестник Омского университета. 2009. № 3. С. 193-199.

Холодковский К.Г. Некоторые вопросы развития массового политического сознания // Мировая экономика и международные отношения. 1979. № 6. С. 126-131. 
Castano E., Bonacossa A., Gries P. National Images as Integrated Schemas: Subliminal Primes of Image Attributes Shape Foreign Policy Preferences // Political Psychology. 2015. Vol. 37. N 3. P. $351-366$. DOI: 10.1111 /pops.12259.

Chugrov S.V. The Image of Russia in Japan and the Image of Japan in Russia: Working Paper 33/2017. Russian International Affairs Council (RIAC). Moscow: NPMP RIAC.

Feklyunina $V$. National Images in International Relations: Putin's Russia and the West. Thesis $\mathrm{PhD}$ in Politics. University of Glasgow, 2009.

Herrmann R.K. \& Fischerkeller M.P. Beyond the Enemy Image and Spiral Model: Cognitive-Strategic Research after the Cold War // International Organization. 1995. Vol. 49 (3). P. 415-450.

Klapper J.T. The Effects of Mass Communication. NY: Free Press, 1960.

Katz E. The Social Itinerary of Technical Change: Two Studies on the Diffusion of Innovation // Human Organization, 1961. Vol. 20. N 2. P. 70-82.

Kunczik M. Images of Nations and International Public Relations. Mahweh. N.J.: Lawrence Erlbaum, 1997.

Li X. \& Chitty N. Reframing national image: A methodological framework // Conflict \& communication online. 2009. Vol. 8. N 2. P. 1-11.

Scott W.A. Psychological and social correlates of international images // International Behavior. Ed. by H.C. Kelman. NY: Holt, Rinehart and Winston. 1966. P. 70-103.

Sears D.O. \& Freedman J. Selective Exposure to Information: A Critical Review // Public Opinion Quarterly. 1967. Vol. 31. P. 194-214.

Tichenor P.J., Donohue G.A. \& Olien C.N. Mass media flow and differential growth in knowledge // Public Opinion Quarterly. 1970. Vol. 34(2). P. 159-170.

Whitehead S. Arab Portrayals in U.S. and British News Magazines: A Comparative Analysis. Paper presented at the Annual Meeting of the Association for Education in Journalism and Mass Communication. 1987.

Yehuda A. The role of intergroup contact in change of prejudice and ethic relations // Towards the elimination of racism. Ed. by P.A. Katz. NY: Pergamon. 1976. P. 245-308.

Youichi I. Socio-cultural backgrounds of Japanese interpersonal communication style // Civilisations. 1991. N 39. P. 101-128.

Zhilina L.V. Representations of neighboring countries at the beginning of $21^{\text {st }}$ century - Russia and Japan in students' imaginations. Omsk: Omskblankizdat, 2008.

Zhilina L. Public attitude and mutual perceptions: Japan and Russia // CEU Political Science Journal. 2015. Vol. 10. N 1-2. P. $1-30$.

Дата поступления статьи: 17.11.2017

Для цитирования: Zhilina L.V. Japanese young people' perceptions of Russia // Вестник Российского университета дружбы народов. Серия: Международные отношения. 2018. Т. 18. № 1. C. 49 -65. DOI: $10.22363 / 2313-0660-2018-18-1-49-65$.

Сведения об авторе: Жилина Лариса Владимировна - кандидат исторических наук, доцент кафедры иностранных языков Омского государственного университета им. Ф.М. Достоевского (e-mail: larissa-zhilina@yandex.ru).

(C) Zhilina L.V., 2018 